\title{
Preparing Teachers for the Challenges of Technology Integration
}

\author{
Mélina Ziegel \\ Teacher's College, Columbia University, New York, USA
}

\author{
mz2001@columbia.edu
}

\begin{abstract}
Technology and the corresponding constructivism are creating an educational agenda where the process of learning is valued at least as highly as the outcome. Since technology entered the classroom, learning goals have expanded from facts and knowledge by subject to intellectual curiosity and a love of learning. Students are engaging in their own meaning-making, or knowledge production, through project-based learning that reflects their interests and abilities rather than solely seeking to meet content area standards. New learning goals for students have greatly altered the role of teachers. This paper will explore some of the primary issues in teacher training and development that accompany technology integration into classrooms including:
\end{abstract}

- What teachers need to learn pedagogically, technically and psychologically to incorporate technology into the curriculum;

- How teachers can learn the necessary skills required for such classroom change; and,

- What role teachers can and should play in the change process.

Keywords: technology integration, teachers, professional development, change process, constructivism

\section{Introduction}

Models of technology integration that maximize the benefits of using computers to aid learning allow students the flexibility to explore and use their own inspiration to complete assignments within the rubric for each project. The use of technology in education is slowly shifting from use as a tool for its own sake to a separate set of curricular learning goals necessary for a variety of competencies. However, in many schools integration has been halted or has occurred in less-thanoptimal manners like teachers only allowing students to use drill-and-kill software. Particularly in the United States where teachers face a number of contextual constraints, a policy agenda to assist in the planning, implementation, and maintenance of technology-based programs in schools is essential. This paper will highlight the issues that arise with respect to preparing and appropriately supporting teachers before, during and after the initial technology implementation in their

Material published as part of this journal, either on-line or in print, is copyrighted by Informing Science. Permission to make digital or paper copy of part or all of these works for personal or classroom use is granted without fee provided that the copies are not made or distributed for profit or commercial advantage AND that copies 1) bear this notice in full and 2) give the full citation on the first page. It is permissible to abstract these works so long as credit is given. To copy in all other cases or to republish or to post on a server or to redistribute to lists requires specific permission from the publisher at Publisher@InformingScience.org classrooms, schools, and the field of education so that all students can experience an optimal level of technology as part of their educational journey. 


\section{An Overview of the Benefits of Technology in the Classroom}

There are several benefits associated with incorporating technology into the classroom that should be highlighted for policymakers. First, technology facilitates the ability to bring real-world applications to lessons, which allows for professional training long before entry into the workforce. For example, the science teacher in one New York City middle school built collaborations for her students to participate in, like real laboratory experiences at the City College of New York and the STARS program through which National Aeronautics and Space Administration (NASA) astronauts provided students feedback on science projects. This encouraged students to examine and consider the implications of their school projects in the "real" world as well as making them view their work in a professional context. This type of project increases the students' ownership and pride in their work which can lead to increased engagement, better (i.e. more and more comprehensive) learning, and the resulting testing success, as well as more focused training for future career prospects.

The type of project facilitated by technology helps teachers teach leadership by giving students life skills including the ability to present themselves and their ideas; to solve problems; and to think critically. Technology can also assist in the seamless transfer of knowledge and skills from one area to another using project-based learning. By working on challenging, interdisciplinary, long-term projects, students grow an interest in and/or love for learning as well as tap their potential and release the fear of taking risks. A focus on the learning process teaches the internal mechanisms used to think a problem through. Students learn to take initiative, make decisions, and embrace the opportunity to present and evaluate ideas that can contribute to a sense of personal fulfillment.

Technology-incorporated constructivist classrooms provide other benefits because of improvements to student motivation that accompany such innovation. For example, such educational opportunities may lesson the wide gulf between the educational accomplishments of children of different social class and racial backgrounds because students can develop projects more in line with their interests than is possible in traditional text-based classrooms. In this way, students get to experience schooling as a process to which they are willingly attracted, not a compulsory one. Students can acquire knowledge and skills that are not the consequences of rote learning or of memory or abstractions devoid of personal experience but rather acquired in a way that is interrelated and gives personal purpose to present and future. These interactive learning models engender interest in and curiosity about human accomplishments at the same time as students learn about the domain of career options and how schooling relates to these options in the fastchanging world of work (Sarason, 1991.) These highlight the benefits of active learning and encourage a love of learning in addition to teaching subject matter competencies.

This paper highlights the skills teachers need to develop in order to embrace technology in their classroom practices, the methods and considerations involved in providing teachers appropriate training opportunities, and the expanding role of teachers in the classroom, the school, and the educational arena.

\section{What Teachers Need to Know to Teach with Technology}

Technology integration in the classroom can mean that teachers need training in a variety of competencies. Teachers who have not previously used computers may need technical training. Teachers may also need to learn how to design the type of lessons that capitalize on the benefits of technology. This includes training specific to using the Internet and developing online projects. The school's change may also allow for leadership training for teachers, such as developing those 
skills that would promote team-building for teachers to work together to design projects. These teacher collaborations are key because they can facilitate critical inquiry, reflection and dialogue essential to educational change. This section will highlight some of the most important areas of teacher training required for schools to embrace technology integration in the classroom and school.

\section{Technical Training}

One consideration for schools wanting to implement technology is developing sufficient technical competency in house. Although technology coordinators or consultants can assist teachers and address hardware and networking issues, teachers also need to be trained in the variety of requisite skills for successful technology integration and maintenance. Teachers need to learn about hardware and software including connectivity and networking issues as well as be sufficiently comfortable with their course content to give students the freedom and flexibility in their projects that technology facilitates.

\section{Training to Teach with Technology}

Teachers that successfully incorporate technology into their classrooms often use a constructivist framework with project-based teaching methods. Teachers need to be aware of and learn to address the implications for curriculum choice, learning goals, project selection and classroom management. Teachers must learn to use technology only in instances where it is the tool that best supported the learning goal. For example, although temperature gages can be attached to laptops to make measurements for science labs, the students can concurrently use textbooks and conduct experiments with lab supplies (not by computer simulations) and then use their laptops to record, evaluate, and present information. In this way, no skill set is lost and technology enhances, but does not replace, traditional learning aims or processes.

One challenge for teachers is to design or find and implement technology-incorporated assignments that are conducive to helping students learn the skills and knowledge required by the mandated curriculum. Regardless of the learning facilitated by technology itself and by technologybased projects, in the current climate, teachers ultimately need to prepare students for testing. This means that in addition to seeking model projects that could be adopted for specific content areas, successful teachers will also seek out technology-specific guidelines that highlight how to use technology to enhance learning. These, like the International Society for Technology in Education (ISTE) standards, Edutopia and technology curriculum developed by the George Lucas Educational Foundation, help identify learning needs and objectives specific to technology-based classrooms. Among the new goals, this teaching philosophy seeks to help students improve communication, promote investigation, and inspire creativity. By actively engaging students in the material, they are more likely to learn and test well. By teaching with technology, e.g. such tools as LCD projectors, students can see every keystroke done by a teacher during a Powerpoint presentation or web search. In this way, the teachers are able to model the problem-solving behavior and tools for their students, optimally confirming the intellectual curiosity and decision making that needs to underlie successful learning with technology. For example, students who watch their teachers deal with "File Not Found" on Websites are, as a result, less likely to become frustrated when they have the same experience. This new classroom dynamic can facilitate reaching educational goals because students are engaged in their own learning.

A fundamental change towards technology-based projects challenges teachers to rethink not only lesson plans to meet curricular goals, but also their classroom management and discipline practices. Providing students with computers, and especially Internet access, means that playing games, surfing the Web and other activities that are different from the class assignment can easily 
distract their attention. Educators need to learn and understand the effect of the novelty of such tools in the classroom. The result of this novelty is that teachers must be especially creative with their projects in order to insure that students are sufficiently engaged to not be bored but be motivated and inspired to participate. In many cases, teachers will face added equity challenges teaching students who come from poor backgrounds as they will face even greater difficulty compensating for a lack of technological and other home supports. Teachers in some classes may struggle with disciplinary problems from students needing additional technical help. As a result, they may be constrained in their ability to introduce technology-based projects without providing technical training or having additional staff available for supervision.

\section{World Wide Web Training}

Teachers can help students capitalize on the advantages of finding and analyzing large amounts of information, which is useful in the academic arena and in many professional situations, by incorporating Internet-based research. This skill can establish critical inquiry by emphasizing the usefulness of multiple sources and types of methods, information and knowledge. For example, in one sixth-grade technology-integrated math class, the teacher introduced a unit on kites, a lesson that incorporated math, science, history, and writing. The teacher began the lesson by encouraging students to ask questions about kites and then facilitated small and large group conversations where students compared the answers they found online to questions like: Who invented kites? What makes them fly? What were they used for? By pursuing their interests, students were able to learn from their own research and from their classmates about geometric shapes, the physics of materials and properties that are conducive to flying, as well as the history of kites and their uses. Students produced mathematical calculations about the kites they ultimately built and wrote about the experiences relating to kites that they found online (George Lucas Educational Foundation, 2001.)

Since specific technologies tend to have only very limited periods of real benefits, people that use it must keep learning new things. Continual learning, continual improvement, and being continually curious is essential to remaining competitive in the workplace. In order for students to be continually engaged in the learning process, teachers must find creative ways to teach their content areas, technology, and a fundamental love of learning simultaneously. The value of education itself as a process and not just as a one-time endeavor will become a new goal of education and students who are viewed and trained as intentional, "perpetual students" will be ahead. Starkweather says that:

Leaders in the technology teaching profession know that technology education cannot be a stagnant subject if properly taught. Technology is a dynamic, constantly changing subject area in which the teacher must be ready to make frequent changes to stay current with advancing innovations. Technology teachers are expected to constantly explore advancements in the technological world for implementation into their curriculum and to lead their students in making similar explorations. [But he cautions] ...Such curriculum advancements are uncommon in education. In fact, stagnation of a content area is all too common. No other subject area has the unique requirement of 'capturing' innovation. Nor do other subject areas specifically aim at developing one's ingenuity using technology to solve societal problems (Starkweather, 2002.)

A resulting challenge is for educators to rethink research projects that allow students the freedom to go online. Previously, teachers who used printed materials, like Encyclopedias and other books, could be more or less familiar with all of the sources that students were likely to use. However, if students are free to seek information on the Web, it is impossible for teachers to be expected to know everything that might pique a student's interest. Teachers have to be comfort- 
able with this uncertainty and allow students more control in their lessons. For example, if primary web-sites are unavailable, teachers need to have alternative sites ready or let students discover other options on their own.

\section{Creating an Engaging Learning Environment}

Another issue is to create a learning environment that constantly engages all of the students. While this may seem daunting, a project that allows such individualized expression helps each student grasp the material in the most meaningful way for him/her. One such example relates directly to the level of technology use. In a New York City school with a school-wide laptop program (for all students and teachers), the school created a grade-by-grade teaching hierarchy whereby students learned technology incrementally. Students learned terms first (like 'browser', 'network'), then skills (like html and JAVA), then business applications using the skills, and architecture. In addition to providing a framework for teaching technology in a developmentally appropriate manner, this facilitated meeting curricular goals. The level of technology capabilities grew in sync with the increasingly challenging and engaging projects. The importance of projectbased learning in the context of this incrementally gained knowledge about computers cannot be underestimated: since students help define their own learning goals (in the context of the teacher's lesson objectives), their boredom factor is limited.

\section{How Teachers Can Learn What They Need to Know to Teach with Technology}

With respect to teacher training, a number of issues must be addressed. First, what type of training is appropriate and for whom (not all teachers could, or arguably should, participate in the technology movement) needs to be determined. Training could include basic computing (i.e. keyboarding skills), specific software programs (i.e. Microsoft Word, Inspiration), and even fixing basic hardware problems. Furthermore, teachers unfamiliar with the World Wide Web need training in locating and critiquing information found online. Bybee and Loucks-Horsley (2000) describe the three key areas of professional development as:

- learning about and developing skills related to technology;

- learning about how to teach technology; and,

- providing teachers tools to motivate them to continue their own learning.

The professional development plan should be selected and designed with an understanding of the relationships and skills of the teachers in a given school. Teachers can have online mentors, they can meet to discuss technology issues and pedagogical or project-related ideas, and a technology specialist can be incorporated into the school's staff to assist with the implementation and support the teachers. In the Apple Classrooms of Tomorrow project, teachers discussed the value added in their own methods and philosophy about teaching created by reflecting with each other, but this need decreased and faded as the teachers' comfort level grew (Sandholtz, Ringstaff, \& Dwyer, 1997.) Teachers who demonstrate comfort and competence early on may be able and willing to share model lesson plans and teaching methods with their peers.

This strengthening of teacher relationships can also create an environment in which both process and practice-based models are used to solve issues (Brown and Duguid, 2000.) In the processbased model, people find meaning in functional explanations and tend to address issues of meaning in the context of larger goals. Practice-based models, on the other hand, focus on accomplishing a particular task, and by so doing, create a situation in which people rely on others in similar positions or of similar rank to find out what they do and why rather than asking for help from su- 
pervisors. In a school where teachers affect the technology integration process in conjunction with school and district administrators, they can employ both process- and practice-based thinking by relying upon school-wide initiatives and each other to find successful classroom methods. For example, teachers can develop projects that teach required standards but allow students the freedom to work together, using a variety of sources (and types of sources), towards a clear and consistent deliverable.

\section{How Teachers can Participate in the Change that Accompanies Technology Integration}

There are many benefits derived from including teachers in the change process that results from technology integration in schools. Firestone describes the term "participation" as formal opportunities for teachers to be present during the process of making decisions about school improvement (Firestone \& Corbett, 1989.) The three reasons to include teachers in the process are:

- increasing their commitment to the new practice;

- developing the local capacity for implementation; and,

- improving the likelihood of appropriate changes in a given, specific setting.

One example of how this can be implemented is for a school's hiring procedure for teachers to become a collaborative one in which a team of teachers interviews prospective applicants. This places school practitioners in central decision-making roles. While these opportunities are exciting and valuable, they create some concerns. For example, for teachers to be able to participate in the change process, those in authority need to grant them time to attend meetings and conference with each other so that these do not interfere with the teachers' primary duties. Also, the changing relationships between teachers included and not included in the change process should be monitored.

Riel and Becker discuss the key role played by "teacher leaders" in implementing and perpetuating new initiatives in schools (2000.) These professionals give conference presentations, spend time on academic publishing and undertake formal and informal professional discussions. This professional engagement signifies a commitment to participate in educational discussions at levels greater than the classroom or even school. These teachers are those that could, for example, interview potential candidates for teacher openings to make sure there is a "fit" after the implementation has begun. Particularly with the relative ease of participating in a national or global discussion about education by using technology (i.e. posting to Websites and sending e-mail), teachers that are implementing technology are in an excellent position to exercise roles as "teacher leaders."

One way for teachers to participate in the global teaching community is to provide leadership and assistance in selecting and disseminating information about the primary competencies and skills on which schools should focus. The best schools are teaching students how to locate information and critically analyze, evaluate, condense, and use it. In 2002, ISTE revised its Educational Computing and Technology Standards. The new Standards were developed from their 1998 National Educational Technology Standards (NETS) that were designed to support the development of technology-capable P-12 students, who must, in today's world, become:

- Capable information technology users,

- Information seekers, analyzers, and evaluators,

- Problem-solvers and decision-makers, 
- Creative and effective users of productivity tools,

- Communicators, collaborators, publishers, and producers, and

- Informed, responsible, and contributing citizens (ISTE, 2002.)

These standards represent the first and most widespread attempt to identify the unique skills required of computer users as well as how to incorporate these skills into learning in each academic area. Again, teachers are the primary resource to develop standards and models for technology integration in schools, initially and in the long run. For example, teachers can submit sample lesson plans or present at conferences about their innovations in the classroom. Not only does this assist other educators, but it brings the policy issues related to such changes, such as assessment, equity, financial planning for appropriate training, and infrastructure concerns, to the forefront for educational policymakers. Especially for classes and schools that are among the first to incorporate technology, the teachers will be in a special situation where they may be profiled as a model and hailed as a "success" and will be able to provide good starting tips for other schools. Schools that have successfully implemented portfolio assessments for projects and continue to have their students succeed on standardized tests may be able to provide information necessary to make policy decisions about appropriate assessment methods in this new classroom model. These forerunners can help create industry-wide change.

These leaders can also assist in bridging the generation gaps in teaching and learning styles between veteran teachers, incoming teachers, and the students they serve. Not only must professional development be a top priority if teachers are to be given tools appropriate for teaching and incorporating technology, schools may have to create policy to deal with teachers who are not willing or able to build the requisite skills for what they need to teach. Teachers will have to be (re)taught how to build a strategy that takes course content and shapes it into an effective plan for teaching and learning (Reeve, 2002.) This will become a key set of initiatives for decision-makers inside and outside the school.

\section{Conclusion}

Teachers need to be appropriately prepared to bring technology into their classrooms and into their schools (not to mention the schools' communities.) In addition to technical training and addressing pedagogical questions, they can and often should participate in the change process in order to provide support and assure the perpetuity of successful advances towards an engaging learning process for all students.

The shift in the teaching and learning paradigm (both pedagogical and relating to content area) as a result of technology integration is raising questions about professional development for teachers; assessment mechanisms; and, even the purpose of education. Educators and concerned citizens (especially parents) need to work to advance the beliefs and understanding about new educational necessities. Teachers should help the public understand the shift in the timing, place, and actors in the process of knowledge production and how those factors change the classroom and makes its requirements even more challenging but necessary in the preparation of its young people. Educators need to gather support to define curricular goals integrating technology, including identifying optimal ages and aims achieved by specific teaching methods.

Assessment is an area around which debate is heated. It is difficult to identify appropriate measures to test the skills that a technology-enhanced classroom experience seeks to bestow upon its students. For example, how do you measure if a student's decision-making, critical thinking or teamwork skills have improved over time? How do you determine if a student can appropriately locate, evaluate, and compile Internet research in order to identify key points? Can tests be developed to measure these educational outcomes? Moreover, the issue is complicated in the United 
Preparing Teachers for the Challenges of Technology Integration

States by a politically charged climate of high-stakes testing, where it is difficult for teachers to recommend and promote alternative assessment plans, like portfolios.

There are two other challenges for educators: namely, the perception of the role of education and funding. The International Technology Education Association partnered with Gallup to poll U.S. citizens about their views on technology teaching (Starkweather, 2002.) Among the findings were that while people are aware that technology exists and that they are required to possess varying amounts of knowledge in order to function in such a society, many think people are trained rather than educated on how to use technology. For example, such training can occur when we learn to use an ATM machine, a cell phone, or a video game. This means that educators must first convince decision-makers as well as the general public that technology should and must be incorporated into an educational mission. This is particularly salient given that it is these people who control funding available to schools. Stover found that only $37 \%$ of a school's outlay is spent on hardware; the remainder is in "hidden costs" like training, maintenance, and support (Stover, 1999.) Educating the public (including politicians and parents) on the demands of a technologybased school program must occur for the appropriate level of funding to accompany the pedagogical and curricular paradigm shifts discussed earlier. Only when these conditions are met can educators meet the challenge of the $21^{\text {st }}$ century.

\section{References}

Brown, J. \& Duguid, P. (2000). The social life of information. Boston, Massachusetts: Harvard Business School Press.

Bybee, R. \& Loucks-Horsley, S. (2000). Advancing technology education: The role of professional development. The Technology Teacher.

George Lucas Educational Foundation. (2001). Laptops for all. Retrieved October 25, 2003, from http://www.digitaldividenetwork.org/content/stories/index.cfm?key=219

Firestone, W., \& Corbett, H.D. (1989). Planned organizational change. In N. Boylan (Ed.), Handbook of research on educational administration (pp. 321-327). New York: Macmillan.

ISTE. (2002). Educational computing and technology standards. Retrieved October 2003, from http://cnets.itse.org/

Reeve, E. (2002). Translating standards for technological literacy into curriculum. The Technology Teacher, 62 (2), 33-36. Retrieved from http://www.iteawww.org/TAA/LinkedFiles/Articles/TTTpdf/2002-03Volume62/reeve_oct02.pdf

Riel, M. \& Becker, H. (2000). The beliefs, practices, and computer use of teacher leaders. Retrieved September 2002, from http://www.crito.uci.edu/tlc/findings/aera/aera.htm

Sandholtz, J., Ringstaff, C. \& Dwyer, D. 1997. Teaching with technology: Creating student-centered classrooms. New York: Teacher's College Press.

Sarason, S. (1991). The predictable failure of educational reform. New York: Jossey-Bass.

Starkweather, K. (2002). ITEA Gallup Poll: Interpreting what others think of technology teaching. The Technology Teacher, 61(8), 31-33. Retrieved from http://www.iteawww.org/TAA/LinkedFiles/Articles/TTTpdf/200102Volume61/starkweather_mayjun02.pdf

Stover, Del. (1999). No hiding technology's hidden costs. The Education Digest, 64 (9), 36-38. 


\section{Biography}

Mélina Ziegel is completing her Doctorate in Education at Teacher's College at Columbia University in the City of New York. Her dissertation examines the interdependent components of the change process relating to technology integration in public New York City middle schools. She seeks to delineate components of successful integration that can be modeled by other schools as they embark on the process of incorporating technology into classrooms to enhance their students' learning opportunities. She has completed a Master's in Education from Teacher's College, for which she surveyed $6^{\text {th }}$ and $8^{\text {th }}$ grade student perceptions of the benefits of computers on the learning experience in the home, school, and community environments. She also has a Master's in Public Policy with a concentration in Family \& Child Policy from the Harris School at the University of Chicago. She has implemented several technology-based programs for homeless and low-income children in New York City and has taught students ranging from five years through adult age. 